\title{
Credit default swaps and regulatory capital relief: evidence from European banks
}

\author{
By \\ John Thornton \\ The Business School, Bangor University, College Road, Bangor, Gwynedd, LL57 2DG, UK and \\ Office of Technical Assistance, United States Department of the Treasury, 1750 Pennsylvania \\ Ave NW, Washington DC 20006, USA. Email: j.thornton@bangor.ac.uk; \\ john.thornton@otatreas.us (Corresponding author). \\ and \\ Caterina di Tommaso \\ Department of Economics, Università della Calabria, Italy \\ Email: caterina.ditommaso@unical.it
}

\begin{abstract}
In a sample of European banks, we find that credit default swaps (CDS) are used for regulatory arbitrage to lower capital requirements and facilitate greater risk taking. Moreover, CDS-using banks generate higher returns on capital from the lower risk weighted assets they hold relative to banks that do not use CDS.
\end{abstract}

J.E.L. Classification: G01, G18, G21, G22, G28.

Key words: credit default swaps, regulatory arbitrage, European banks 


\section{Introduction}

Bank capital standards (e.g., Basel III; the European Union's (EU) Capital Requirements Regulation (CRR)) allow banks to reduce their required regulatory capital by using credit default swaps to transfer credit risk to third parties. ${ }^{1}$ This is a concern for at least three reasons (Cetina et al. 2015). First, even if real risk transfer takes place, these transactions pose financial stability concerns by increasing interconnectedness, transforming credit risk into counterparty risk, and obscuring capital adequacy to investors and counterparties. Second, while bank supervisors have extensive data about banks, they may have limited information about the nonbanks who are selling credit risk and ultimately bearing the risk of loss. ${ }^{2}$ Third, and the focus of this paper, a bank with a low regulatory capital ratio has an incentive to buy CDS to obtain regulatory capital relief by reducing the risk weights of corporate loans-i.e., CDS may be used for regulatory arbitrage to lower capital requirements. Research on CDS usage for regulatory capital relief is surprisingly limited. Pennacchi (1988) and Allen and Carletti (2006) suggest that banks may choose to transfer credit risks when facing capital and liquidity constraints, implying that banks can buy CDS to obtain regulatory capital relief by reducing the risk weights of their loans. Yorulmazer (2013) develops a theoretical model that predicts CDS can be used for regulatory arbitrage to lower capital requirements potentially resulting in excessive risk taking. Empirical evidence is restricted to Shan et al. (2014) and Hasan and Wu (2015) who report results supportive of the regulatory capital relief hypothesis. Shan et al. (2014) document that US banks' total assets increase after they begin using

\footnotetext{
${ }^{1}$ A key property of credit derivatives is that they separate the origination of credit, the funding of credit, and the holding and management of credit risk. Thus, banks that originate credit to corporate borrowers need no longer hold the credit risk associated with these loans, while other financial firms can hold credit risk without having to originate or fund the underlying credit.

${ }^{2}$ Cetina et al. (2015) point out that when AIG came under stress in 2008, European banks faced losing some of the $\$ 290$ million in CDS protection that they had purchased from the company for regulatory capital relief.
} 
CDS, while their risk weighted assets decrease, which they argue is an unintended consequence of bank capital regulations that allow the use of CDS to convert high risk weighted assets into low risk weighted assets. As such, banks can use CDS to hold less capital while complying with the requirements of regulatory capital ratios. In addition, CDS using banks generate higher returns on capital from the lower risk weight assets that they hold than do banks not using CDS. Hasan and $\mathrm{Wu}$ (2016) find a negative and significant correlation between net CDS protection and the regulatory capital ratio for US banks.

In this paper, we test the regulatory relief hypothesis by examining CDS usage in a sample of European banks. The shift in focus from US banks is merited for three reasons. First, banks are considerably more important to finance in Europe, whereas there is a much greater reliance on the corporate bond market and other nonbank sources of finance in the US. ${ }^{3}$ This arguably makes the stakes in ensuring the safety of the banking system even higher in Europe (Cline 2017). Second, European banks use International Financial Reporting Standards (IFRS) while US banks use Generally Accepted Accounting Principles (GAAP). Because IFRS does not permit the netting out of derivatives, the reported assets of European banks tend to be larger than would be reported under GAAP and total leverage exposure tends to be much closer to total assets (Goldstein, 2017). Accordingly, the incentive to engage in regulatory arbitrage might be greater for European banks. Finally, our sample of European banks includes eleven that have been designated as globally systemically important banks (GSIBs) by the Financial Stability Board. ${ }^{4}$ Though the additional

\footnotetext{
${ }^{3}$ For example, Merler and Véron (2015) estimate that in 2014, in the euro area bank loans accounted for $88 \%$ of financing to nonfinancial companies and debt securities only $12 \%$, whereas in the US the share of loans was only $30 \%$ and that of debt securities $70 \%$.

${ }^{4}$ For a list of GSIBs see http://www.fsb.org/2017/11/2017-list-of-global-systemically-important-banks-g-sibs/.
} 
capital requirements for these banks under Basel III rules were not in place during our sample period, the expectation of higher capital requirements may have provided them with an additional incentive to engage in regulatory arbitrage.

Our paper makes several contributions to the banking literature. First, it contributes to the growing literature on financial institutions' activities that circumvent regulatory requirements by strategically managing their balance sheet variables to appear in compliance with regulatory requirements while engaging in additional risk taking. Second, we focus on how banks manage their risky portfolios from the perspective of bank capital and present direct evidence on how capital management is affected by the regulatory forbearance afforded by CDS. Third, in the design of bank regulation, policymakers are concerned about whether banks use CDS to hedge the risk of corporate lending, provide credit enhancement, obtain regulatory capital relief, or exploit private information.

\section{Models}

We carry out three tests of the regulatory relief hypothesis in the context of CDS usage by estimating Shan et al. (2014) and Hasan and Wu (2015)-type specifications for European banks. First, if banks use CDS for capital relief purposes, we should expect that banks that are more capital constrained are more likely to use CDS. Accordingly, we examine whether European banks that have a lower capital ratio in the prior quarter are more likely to use CDS in the next quarter by estimating the following specification: 


$$
C D S_{-} d u m_{i t}=\alpha+\beta_{1} C A P 1_{i t-1}+\delta X_{i t}+\delta_{i}+\varphi_{t}+\varepsilon_{i t}
$$

where the dependent variable, $C D S_{-} d u m_{i t}$, is a dummy taking the value of one if the bank takes a non-zero CDS position in quarter $\mathrm{t}, C A P 1_{i t-1}$ is the ratio of tier 1 capital to total risk weighted assets lagged one period, ${ }^{5} X_{i t}$ is a vector of bank characteristics that may impact on CDS usage, and $\delta_{i}$ and $\varphi_{t}$ capture bank and year fixed effects, respectively.

Second, if banks use CDS for capital relief purposes we should expect that CDS using banks would achieve lower levels of risk weighted assets relative to total assets than would non-CDS using banks. We test this hypothesis by examining the impact of CDS usage on the total of banks' risk weighted assets by estimating the following specification:

$$
\left(\frac{R W A}{T A}\right)_{i t}=\alpha+\beta_{1} C D S_{-} d u m_{i t}+\delta X_{i t}+\delta_{i}+\varphi_{t}+\varepsilon_{i t}
$$

where the dependent variable, $\left(\frac{R W A}{T A}\right)_{i t}$, is the ratio of risk weighted assets to total assets for each bank and the variables $C D S_{-} d u m_{i t}, \delta X_{i t}, \delta_{i}$, and $\varphi_{t}$ are as defined in equation (1).

Finally, Shan et al. (2014) argue that, ceteris paribus, banks using CDS for capital relief purposes should achieve a higher return on capital than banks that do not use CDS, reflecting the capital 'saving' involved. They test for this possibility by examining the change in the return on equity after banks' CDS usage in the following specification:

\footnotetext{
${ }^{5}$ We use the ratio of tier 1 capital to risk weighted assets to measure bank capital adequacy because it is the best core measure of a bank's financial strength.
} 


$$
R O E_{i t}=\alpha+\beta_{1}\left(\frac{R W A}{T A}\right)_{i t}+\beta_{2} C D S_{-} d u m_{i t}+\delta X_{i t}+\delta_{i}+\varphi_{t}+\varepsilon_{i t}
$$

where the dependent variable, $R O E_{i t}$ is the return on equity, and $\left(\frac{R W A}{T A}\right)_{i t}, C D S_{-} d u m_{i t}, X_{i t}, \delta_{i}$, and $\varphi_{t}$ are as defined above.

We estimate equations (1) - (3) employing a panel of quarterly data for 50 European banks from 14 European Union countries for the period 2001Q1 to $2016 \mathrm{Q} 1 .^{6}$ The control variables in $X_{i t}$ include measures of bank size, net income structure and growth, market share, the return on equity and its volatility, liquidity, funding structure, and the notional amount of securitized assets. Summary statistics for the key variables are presented Table 1 and variable definitions and sources are given in the Appendix. Studies at the level of individual banks face an inherent endogeneity problem arising from reverse causality. For instance, it may be that a change in aggregate CDS position at the individual bank level affects a bank's regulatory capital ratio. In other words, banklevel explanatory variables on the right-hand side of a regression could be endogenous. We have lagged the explanatory variables to try to deal with this issue but recognize that endogeneity bias could still arise from serial correlations of the explanatory and dependent variables.

\section{Empirical results}

Estimates of equation (1) are reported in Table 2. In column 1 the coefficient of the lagged-onequarter Tier 1 capital ratio is -0.044 , which is statistically significant at the $1 \%$ level, and indicates

\footnotetext{
${ }^{6}$ The countries are Austria, Belgium, Denmark, France, Germany, Greece, Ireland, Italy, Netherlands, Portugal, Spain, Sweden, Switzerland, and the UK.
} 
that lower capital adequacy is associated with a higher likelihood of using CDS after controlling for other variables that may affect a bank's incentives to use CDS. The coefficients on the control variables suggest that there a higher likelihood of a bank using credit derivatives if it is relatively large, has a larger share of the deposit market, a higher return on equity, a larger share of funding is from bank deposits, a larger share of assets is securitized, and a higher share of income is from non-interest sources. Conversely, there is a lower likelihood of CDS usage if the return on equity is more volatile and the bank is relatively liquid. In column 2, we try to account for any differential impact on CDS use by globally systemically important banks (GSIB) by adding a 0-1 dummy ( $1=$ GSIB) to the estimate. The coefficient on the dummy variable is positive and statistically significant and suggests an increase in the probability of GSIBs using CDS of about $3.4 \%$ relative to other banks. However, the GSIB dummy seems likely to be capturing largely size effects as the bank size variable in the estimate is no longer statistically significant. In column 3 , we replace the CDS use dummy indicator with a continuous variable that measures a bank's CDS usage, which is the logarithm of the CDS position (i.e., the sum of the bought (long) and sold (short) CDS positions by a bank). As for the result in columns 1 and 2, the coefficient of the lagged Tier 1 capital ratio is negative and statistically significant at the $1 \%$ level and indicates that decrease in the Tier 1 capital ratio leads to an increase in the bank's CDS total position in the next quarter. In column 4 we add the GSIB dummy, which again suggests a greater probability of these banks using CDS.

Estimates of equation 2 are reported in Table 3. The results in column 1 and 2 show that CDS using banks have a smaller ratio of risk weighted-to-total assets, consistent with a bank moving its existing assets to a lower-risk category. For example, in column 1, on average, the risk weighted 
assets ratio is lowered by 0.111 (or $17.8 \%$ relative to the sample mean of the risk weighted assets ratio) after banks start using CDS. The result in column suggests a great probability that GSIB will lower their risk weighted assets relative to other banks. Columns 3 and 4 report results when the CDS use indicator is the logarithm of total CDS contracts and columns 5 and 6 reports results when it is the logarithm of the amounts of CDS sold by each bank (because if banks can reduce their risk weighted assets using CDS, then the effects should be more relevant to CDS bought than CDS sold). In each sets of results, there is a negative and statistically significant association between the CDS position and the risk weighted assets ratio. In all the estimates, the coefficients on the GSIB dummy indicate the reduction in the risk weighted asset ratio of GSIBs is greater than that of other banks.

Estimates of equation (3) are reported in Table 4, where we present results using the alternative indicators of CDS use and the bank-specific control variables. The results show that CDS use has a positive and highly statistically significant impact on the return on equity, consistent with CDS use 'saving' bank capital. In addition, the coefficients on the ratio risk weighted assets ratio are positive and statistically significant suggesting that a riskier asset portfolio generates a higher return on equity. Finally, the return on equity increases when a larger share of bank funding is from deposits and falls when a larger share of bank assets is securitized. These results continue to hold when controlling for GSIB banks (columns 2.4,6 and 8), where the coefficients on the GSIB dummy indicate a relatively larger return on equity for these banks than for others.

\section{Conclusion}


Our results for European banks indicate that credit default swaps are used to engage in regulatory arbitrage, and that CDS use generates higher returns on capital because of the lower ratio of risk weighted assets that results. Our results imply that: (i) the calculation of risk exposure under the Basel III and the EU's CRR capital rules may not reflect the actual risk of banks that use CDS when counterparty risk is considered; and (ii) a lower ratio of risk weighed to total assets does not necessarily indicate that a bank's asset portfolio is less risky. The results are consistent with recent empirical work on CDS use in US banks. 


\section{References}

Allen, F., Carletti, E., 2006. Credit risk transfer and contagion. Journal of Monetary Economics $53,89-111$

Cetina, J., McDonough, J., Rajan, S., 2015. More transparency needed for bank capital relief. Office of Financial Research Brief 15-04, June 11.

Cline, W.R., 2017. The right balance for banks: theory and evidence on optimal capital requirements. Policy Analysis in International Economics 107. Petersen Institute for International Economics, Washington DC.

Goldstein, M., 2017. Banking's final exam: stress testing and bank capital reform. Peterson Institute for International Economics, Washington DC:

Hasan, I., Wu, D., 2016. How large banks use CDS to manage risks: bank-firm-level evidence. Bank of Finland Research Discussion Paper No. 10/2016. Available at SSRN: https://ssrn.com/abstract=2772965

Merler, S., Véron, N., 2015. Moving away from banks: comparing challenges in China and the European Union. In China's economic transformation : lessons, impact, and the path forward. PIIE Briefing 15-3. Petersen Institute for International Economics, Washington DC.

Pennacchi, G.G., 1988. Loan sales and the cost of bank capital. Journal of Finance 43, 375-396

Shan, S.C., Tang, D.Y., Yan, H., 2014. Did CDS make banks riskier? The effects of credit default swaps on bank capital and lending. Working Paper, Shanghai Advanced Institute of Finance, Shanghai Jiao Tong University.

Available at: www.sef.hku.hk/ yjtang/ShanTangYan_CDSBanking_08June2014.pdf 
Yorulmazer, T., 2013. Has financial innovation made the world riskier? CDS, regulatory arbitrage and systemic risk. Available at SSRN: $\underline{\text { https://ssrn.com/abstract=2176493 or http://dx.doi.org/10.2139/ssrn.2176493 }}$ 
Table 1.

Summary statistics for European banks, 2001Q1 to 2016Q1

\begin{tabular}{lcccc}
\hline & Mean & $\begin{array}{c}\text { Standard } \\
\text { deviation }\end{array}$ & Minimum & Maximum \\
\hline CDS bought (\$ millions) & 1.13 & 5.54 & 0.00 & 80.27 \\
CDS sold (\$ millions) & 7.87 & 14.80 & 0.12 & 77.91 \\
CDS total (\$ millions) & 9.01 & 20.34 & 0.00 & 158.18 \\
Tier 1 capital ratio (\%) & 12.04 & 6.34 & 1.03 & 91.90 \\
Risk-weighted assets to total assets & 62.69 & 18.41 & 0.10 & 88.53 \\
Size (\$ millions) & 19.65 & 1.30 & 12.38 & 22.00 \\
Return on equity (\%) & 10.02 & 9.26 & 0.04 & 96.80 \\
Return on equity volatility (\%) & 0.15 & 0.31 & 0.00 & 2.28 \\
Liquidity (\%) & 0.13 & 0.35 & 0.00 & 8.27 \\
Market share (\%) & 2.41 & 2.69 & 0.00 & 17.22 \\
Net income growth (\%) & 0.08 & 0.29 & -4.18 & 4.94 \\
Non-interest income/operating income (\%) & 46.27 & 19.56 & 1.06 & 100.00 \\
Total deposits/total liabilities (\%) & 66.41 & 23.78 & 0.22 & 94.34 \\
Securitized assets (\$ millions) & 15.20 & 11.70 & 2.84 & 44.10 \\
\hline
\end{tabular}


Table 2.

Determinants of CDS use by European banks: Logit and panel regression results

\begin{tabular}{|c|c|c|c|c|}
\hline & (1) & (2) & (3) & (4) \\
\hline Dependent variable & \multicolumn{2}{|c|}{ CDS_dum } & \multicolumn{2}{|c|}{$\log (1+\mathrm{CDS})$} \\
\hline \multirow[t]{2}{*}{ Capital ratio } & $-0.044 * * *$ & $-0.078 * * *$ & $-0.142 * * *$ & $-0.125 * *$ \\
\hline & $(0.004)$ & $(0.014)$ & $(0.022)$ & $(0.036)$ \\
\hline \multirow[t]{2}{*}{ Size } & $7.466 * * *$ & 1.315 & $10.013 * * *$ & 3.309 \\
\hline & $(1.025)$ & $(0.955)$ & $(0.913)$ & $(3.186)$ \\
\hline \multirow[t]{2}{*}{ Return on equity } & $0.054 * *$ & -0.061 & $-0.115^{* *}$ & -0.038 \\
\hline & $(0.021)$ & $(0.045)$ & $(0.048)$ & $(0.107)$ \\
\hline \multirow[t]{2}{*}{ Return on equity volatility } & $-3.961 * *$ & $-5.003 *$ & 2.248 & -4.811 \\
\hline & $(1.868)$ & $(2.196)$ & $(4.444)$ & $(4.551)$ \\
\hline \multirow[t]{2}{*}{ Liquidity } & $-0.198 * * *$ & $-0.484 *$ & 0.051 & $-0.756^{* *}$ \\
\hline & $(0.019)$ & $(0.092)$ & $(0.017)$ & $(0.255)$ \\
\hline \multirow[t]{2}{*}{ Market share } & $0.391 * * *$ & $0.616 * * *$ & $0.435 * * *$ & 0.727 \\
\hline & $(0.017)$ & $(0.206)$ & $(0.010)$ & $(0.436)$ \\
\hline \multirow[t]{2}{*}{ Net income growth } & 1.283 & -3.103 & $0.484^{*}$ & $4.699 * *$ \\
\hline & $(1.167)$ & $(2.940)$ & $(0.247)$ & $(1.904)$ \\
\hline \multirow[t]{2}{*}{ Non-interest income/total income } & $0.225 * * *$ & -0.064 & $0.381 * * *$ & -0.132 \\
\hline & $(0.034)$ & $(0.055)$ & $(0.048)$ & $(0.106)$ \\
\hline \multirow[t]{2}{*}{ Deposits/total liabilities } & $0.134 * * *$ & 0.025 & $0.202 * * *$ & 0.092 \\
\hline & $(0.020)$ & $(0.038)$ & $(0.022)$ & $(0.075)$ \\
\hline \multirow[t]{2}{*}{ Log $(1+$ securitized assets $)$} & $5.025 * * *$ & 1.081 & $6.566 * * *$ & 1.068 \\
\hline & $(0.814)$ & $(0.760)$ & $(0.729)$ & $(4.355)$ \\
\hline \multirow[t]{2}{*}{ GSIB dummy } & & $3.419 * * *$ & & $4.311 * *$ \\
\hline & & $(0.955)$ & & $(1.417)$ \\
\hline \multirow[t]{2}{*}{ Constant } & $-55.773 * * *$ & $108.366^{* * *}$ & $-68.686 * * *$ & $166.122 * *$ \\
\hline & $(4.909)$ & $(31.932)$ & $(4.477)$ & $(47.239)$ \\
\hline R-squared & 0.563 & 0.515 & 0.428 & 0.405 \\
\hline Observations & 202 & 202 & 202 & 202 \\
\hline Year fixed effects & Yes & Yes & Yes & Yes \\
\hline Bank fixed effects & Yes & Yes & Yes & Yes \\
\hline
\end{tabular}

Column 1 and report results from a logit regression in which the dependent variable takes the value of 1 if a bank uses credit default swaps and zero otherwise. Columns 3 and report results from a panel regression in which the dependent variable is $\log (1+\mathrm{CDS})$ where CDS equals bank's holdings of credit default swaps. GSIB is a $0-1$ dummy where 1 indicates a globally systemically important bank. Robust standard errors are in parenthesis. ***, ** and * indicate statistical significance at the 1,5 and $10 \%$ levels, respectively 
Table 3.

Risk weighted assets and CDS use in European banks

\begin{tabular}{|c|c|c|c|c|c|c|}
\hline & (1) & (2) & (3) & (4) & (5) & (6) \\
\hline CDS_dum & $\begin{array}{l}-0.111^{* * * *} \\
(0.024)\end{array}$ & $\begin{array}{l}-0.831 * * * \\
(0.209)\end{array}$ & & & & \\
\hline $\log (1+\mathrm{CDS}$, total $)$ & & & $\begin{array}{l}-0.046^{* * *} \\
(0.009)\end{array}$ & $\begin{array}{l}-0.048^{* *} \\
(0.013)\end{array}$ & & \\
\hline $\log (1+\mathrm{CDS}$, bought $)$ & & & & & $\begin{array}{l}-0.086^{* * *} \\
(0.012)\end{array}$ & $\begin{array}{l}-0.109 * * * \\
(0.024)\end{array}$ \\
\hline Size & $\begin{array}{l}-0,065^{* *} \\
(0.028)\end{array}$ & $\begin{array}{l}-0.153 \\
(0.183)\end{array}$ & $\begin{array}{l}-0.752 * * * \\
(0.143)\end{array}$ & $\begin{array}{l}-0.802 * * * \\
(0.156)\end{array}$ & $\begin{array}{l}-0.398 * * \\
(0.170)\end{array}$ & $\begin{array}{c}0.439 \\
(0.297)\end{array}$ \\
\hline Market share & $\begin{array}{l}-0.034^{* *} \\
(0.012)\end{array}$ & $\begin{array}{l}-0.258^{* * *} \\
(0.060)\end{array}$ & $\begin{array}{l}-0.242 * * * \\
(0.036)\end{array}$ & $\begin{array}{l}-0.260 * * * \\
(0.061)\end{array}$ & $\begin{array}{l}-0.212^{* * *} \\
(0.033)\end{array}$ & $\begin{array}{l}-0.239 * * * \\
(0.054)\end{array}$ \\
\hline Net income growth & $\begin{array}{l}-0.088^{* * *} \\
(0.027)\end{array}$ & $\begin{array}{l}0.167 \\
(0.700)\end{array}$ & $\begin{array}{l}-0.312 \\
(0.457)\end{array}$ & $\begin{array}{c}0.202 \\
(0.698)\end{array}$ & $\begin{array}{l}-0.281 \\
(0.440)\end{array}$ & $\begin{array}{c}0.413 \\
(0.763)\end{array}$ \\
\hline Non-interest income/total income & $\begin{array}{l}-0.007 * * * \\
(0.001)\end{array}$ & $\begin{array}{l}-0.032 * * * \\
(0.008)\end{array}$ & $\begin{array}{l}-0.017 * * * \\
(0.005)\end{array}$ & $\begin{array}{l}-0.027 * * * \\
(0.008)\end{array}$ & $\begin{array}{l}-0.032 * * * \\
(0.006)\end{array}$ & $\begin{array}{l}0.055^{* * *} \\
(0.012)\end{array}$ \\
\hline Deposits/total liabilities & $\begin{array}{l}0.010^{* * *} \\
(0.002)\end{array}$ & $\begin{array}{l}-0.005 \\
(0.005)\end{array}$ & $\begin{array}{l}0.001 \\
(0.003)\end{array}$ & $\begin{array}{l}-0.006 \\
(0.005)\end{array}$ & $\begin{array}{l}0.007 * * \\
(0.003)\end{array}$ & $\begin{array}{r}0.004 \\
(0.005)\end{array}$ \\
\hline $\log (1+$ securitized assets $)$ & $\begin{array}{l}0.228 * * * \\
(0.056)\end{array}$ & $\begin{array}{l}1.400^{* * *} \\
(0.289)\end{array}$ & $\begin{array}{l}1.228^{* * *} \\
(0.114)\end{array}$ & $\begin{array}{l}1.310^{* * * *} \\
(0.285)\end{array}$ & $\begin{array}{l}-1.476^{* * * *} \\
(0.126)\end{array}$ & $\begin{array}{l}1.939 * * * \\
(0.363)\end{array}$ \\
\hline GSIB dummy & & $\begin{array}{l}-0.823^{* * *} \\
(0.156)\end{array}$ & & $\begin{array}{l}-0.802 * * * \\
(0.156)\end{array}$ & & $\begin{array}{l}-1.115^{* * * *} \\
(0.186)\end{array}$ \\
\hline Constant & $\begin{array}{l}-3.127 * * \\
(1.081)\end{array}$ & $\begin{array}{l}30.899 * * * \\
(5.630)\end{array}$ & $\begin{array}{l}38.503 * * * \\
(0.114)\end{array}$ & $\begin{array}{l}31.586^{* * * *} \\
(5.862)\end{array}$ & $\begin{array}{l}36.473 * * * \\
(2.460)\end{array}$ & $\begin{array}{l}29.730 * * * \\
(4.888)\end{array}$ \\
\hline R-squared & 0.639 & 0.615 & 0.747 & 0.603 & 0.781 & 0.695 \\
\hline Observations & 236 & 236 & 268 & 268 & 268 & 268 \\
\hline Year fixed effects & Yes & Yes & Yes & Yes & Yes & Yes \\
\hline Bank fixed effects & Yes & Yes & Yes & Yes & Yes & Yes \\
\hline
\end{tabular}

The dependent variable is the ratio of risk weighted assets to total assets. GSIB is a 0-1 dummy where 1 indicates a globally systemically important bank.

Robust standard errors are in parenthesis. *** and ** indicate statistical significance at the 1 and $5 \%$ levels, respectively. 
Table 4.

Return of equity and CDS use in European banks

\begin{tabular}{|c|c|c|c|c|c|c|c|c|}
\hline & $(1)$ & $(2)$ & (3) & (4) & $(5)$ & $(6)$ & $(7)$ & $(8)$ \\
\hline CDS_dum & $\begin{array}{l}3.133^{* *} \\
(1.105)\end{array}$ & $\begin{array}{c}2.447 * * \\
(1.061)\end{array}$ & $\begin{array}{c}2.325^{* *} \\
(0.924)\end{array}$ & $\begin{array}{l}3.561 * * * \\
(1.097)\end{array}$ & & & & \\
\hline $\log (1+\mathrm{CDS}$ total $)$ & & & & & $\begin{array}{l}0.175 * * \\
(0.077)\end{array}$ & $\begin{array}{r}0.196 * \\
(0.104)\end{array}$ & & \\
\hline Log (1+CDS bought $)$ & & & & & & & $\begin{array}{l}0.412 * * * \\
(0.139)\end{array}$ & $\begin{array}{l}0.430 * * * \\
(0.024)\end{array}$ \\
\hline Risk weighted-to-total assets & & & $\begin{array}{r}1.630^{*} \\
(0.962)\end{array}$ & $\begin{array}{l}4.704 * * * \\
(1.378)\end{array}$ & $\begin{array}{l}2.905 * * \\
(1.378)\end{array}$ & $\begin{array}{l}5.148^{* * * *} \\
(1.278)\end{array}$ & $\begin{array}{l}3.927 * * * \\
(1.615)\end{array}$ & $\begin{array}{l}3.066^{* * * *} \\
(1.177)\end{array}$ \\
\hline Size & $\begin{array}{c}1.333 \\
(2.314)\end{array}$ & $\begin{array}{c}1.914 \\
(2.405)\end{array}$ & $\begin{array}{c}0.368 \\
(2.242)\end{array}$ & $\begin{array}{l}0.030^{* *} \\
(0.015)\end{array}$ & $\begin{array}{c}0.993 \\
(1.827)\end{array}$ & $\begin{array}{c}0.030^{*} \\
(0.016)\end{array}$ & $\begin{array}{c}3.433 \\
(2.675)\end{array}$ & $\begin{array}{l}0.062 * * * \\
(0.013)\end{array}$ \\
\hline Market share & $\begin{array}{c}0.783 \\
(0.686)\end{array}$ & $\begin{array}{c}0.716 \\
(0.681)\end{array}$ & $\begin{array}{c}0.687 \\
(0.561)\end{array}$ & $\begin{array}{l}-8.574 \\
(4.963)\end{array}$ & $\begin{array}{c}1.352 \\
(0.899)\end{array}$ & $\begin{array}{l}-9.703 \\
(5.329)\end{array}$ & $\begin{array}{c}1.388 \\
(0.878)\end{array}$ & $\begin{array}{l}-5.792 \\
(3.865)\end{array}$ \\
\hline Net income growth & $\begin{array}{l}-0.616 \\
(3.084)\end{array}$ & $\begin{array}{l}-1.344 \\
(3.128)\end{array}$ & $\begin{array}{l}-0.284 \\
(5.033)\end{array}$ & $\begin{array}{c}1.893 \\
(1.476)\end{array}$ & $\begin{array}{l}-3.343 \\
(7.656)\end{array}$ & $\begin{array}{c}1.899 \\
(1.490)\end{array}$ & $\begin{array}{l}-3.342 \\
(7.293)\end{array}$ & $\begin{array}{c}1.989 \\
(1.499)\end{array}$ \\
\hline Non-interest income/total income & $\begin{array}{l}-0.069 \\
(0.068)\end{array}$ & $\begin{array}{l}-0.006 \\
(0.062)\end{array}$ & $\begin{array}{l}-0.069 \\
(0.068)\end{array}$ & $\begin{array}{l}-1.328 \\
(6.076)\end{array}$ & $\begin{array}{l}-0.048 \\
(0.050)\end{array}$ & $\begin{array}{l}-1.358 \\
(6.126)\end{array}$ & $\begin{array}{l}-0.146 \\
(0.149)\end{array}$ & $\begin{array}{l}-1.161 \\
(5.937)\end{array}$ \\
\hline Deposits/total liabilities & $\begin{array}{l}0.053^{* * * *} \\
(0.014)\end{array}$ & $\begin{array}{l}0.035^{* *} \\
(0.013)\end{array}$ & $\begin{array}{l}0.053 * * * \\
(0.014)\end{array}$ & $\begin{array}{c}0.015 \\
(0.056)\end{array}$ & $\begin{array}{l}0.087 * * \\
(1.598)\end{array}$ & $\begin{array}{c}0.048 \\
(0.056)\end{array}$ & $\begin{array}{l}0.139 * * * \\
(0.043)\end{array}$ & $\begin{array}{l}-0.083 \\
(0.097)\end{array}$ \\
\hline $\log (1+$ securitized assets $)$ & $\begin{array}{l}-3.294 * * * \\
(0.860)\end{array}$ & $\begin{array}{l}-1.543^{*} \\
(0.804)\end{array}$ & $\begin{array}{l}-3.294 * * * \\
(0.860)\end{array}$ & $\begin{array}{l}0.197 * * \\
(0.097)\end{array}$ & $\begin{array}{l}-3.202 * * \\
(1.598)\end{array}$ & $\begin{array}{l}0.106^{* * *} \\
(0.010)\end{array}$ & $\begin{array}{l}-5.334 * * * \\
(2.059)\end{array}$ & $\begin{array}{l}0.195 * * \\
(0.079)\end{array}$ \\
\hline GSIB dummy & & $\begin{array}{l}4.830 * * * \\
(1.385)\end{array}$ & & $\begin{array}{l}4.704 * * * \\
(1.378)\end{array}$ & & $\begin{array}{l}4.174 * * * \\
(2.024)\end{array}$ & & $\begin{array}{l}3.066^{* * *} \\
(1.177)\end{array}$ \\
\hline Constant & $\begin{array}{c}40.911 \\
(39.937)\end{array}$ & $\begin{array}{c}71.122 \\
(41.554)\end{array}$ & $\begin{array}{c}40.911 \\
(39.937)\end{array}$ & $\begin{array}{c}216.987 \\
(137.819)\end{array}$ & $\begin{array}{c}96.952 \\
(68.408)\end{array}$ & $\begin{array}{l}220.023 \\
(139.289)\end{array}$ & $\begin{array}{l}108.951 \\
(70.337)\end{array}$ & $\begin{array}{c}229.189 \\
(142.459)\end{array}$ \\
\hline R-squared & 0.158 & 0.222 & 0.158 & 0.338 & 0.232 & 0.334 & 0.270 & 0.350 \\
\hline Observations & 187 & & 187 & 187 & 187 & 187 & 187 & 187 \\
\hline Year fixed effects & Yes & Yes & Yes & Yes & Yes & Yes & Yes & Yes \\
\hline Bank fixed effects & Yes & Yes & Yes & Yes & Yes & Yes & Yes & Yes \\
\hline
\end{tabular}

The dependent variable is the ratio of the return on equity. GSIB is a 0-1 dummy where 1 indicates a globally systemically important bank. Robust standard errors are in parenthesis. ${ }^{* * *}, * *$ and $*$ indicate statistical significance at the 1,5 and $10 \%$ levels, respectively. 
Appendix Table.

Variable descriptions and data sources

\begin{tabular}{|c|c|c|c|}
\hline Variable & Description & Source & $\begin{array}{l}\text { Expected } \\
\text { sign }\end{array}$ \\
\hline CDS_dum & $\begin{array}{l}\text { Dummy variable equal to } 1 \text { if a bank takes a } \\
\text { nonzero CDS position }\end{array}$ & Bankscope & \\
\hline Net CDS position & $\begin{array}{l}\text { The sum of the notional US dollar amount of } \\
\text { CDS protection bought and sold by each bank }\end{array}$ & Bankscope & \\
\hline Capital ratio & $\begin{array}{l}\text { Ratio of Tier } 1 \text { capital to total risk-weighted } \\
\text { assets for each bank }\end{array}$ & Bankscope & - \\
\hline Size & Natural logarithm of total assets for each bank & Bankscope & + \\
\hline Return on equity (ROE) & $\begin{array}{l}\text { Ratio of net income to common shareholder } \\
\text { equity for each bank }\end{array}$ & Bankscope & + \\
\hline ROE volatility & $\begin{array}{l}\text { The standard deviation of quarterly ROE in the } \\
\text { past four quarters }\end{array}$ & Bankscope & - \\
\hline Liquidity & $\begin{array}{l}\text { Ratio of cash and cash equivalents to total } \\
\text { deposits for each bank }\end{array}$ & Bankscope & - \\
\hline Market share & $\begin{array}{l}\text { Share }(\%) \text { of each bank's deposits in the total } \\
\text { deposits aggregated across all banks in the } \\
\text { sample in each quarter }\end{array}$ & Bankscope/author calculation & + \\
\hline Net income growth & $\begin{array}{l}\text { Ratio of the change in each bank's net income } \\
\text { from quarter } t-1 \text { to quarter } t \text { scaled by total } \\
\text { assets in quarter } t-1\end{array}$ & Bankscope/author calculation & - \\
\hline $\begin{array}{l}\text { Non-interest } \\
\text { income/operating income }\end{array}$ & $\begin{array}{l}\text { Ratio of non-interest income to total operating } \\
\text { income for each bank }\end{array}$ & Bankscope & + \\
\hline Total deposits/total liabilities & $\begin{array}{l}\text { Ratio of total deposits to total liabilities of each } \\
\text { bank }\end{array}$ & Bankscope & + \\
\hline Securitized assets & $\begin{array}{l}\text { Natural logarithm of the outstanding amount of } \\
\text { each bank's securitized assets }\end{array}$ & Bankscope & + \\
\hline GSIB dummy & $\begin{array}{l}\text { Dummy variable equal to } 1 \text { if a bank is globally } \\
\text { systemically important }\end{array}$ & $\begin{array}{l}\text { http://www.fsb.org/2017/11/2017- } \\
\text { list-of-global-systemically- } \\
\text { important-banks-g-sibs/ }\end{array}$ & $?$ \\
\hline
\end{tabular}

